\title{
Measure and Compare Some Heavy Metals in Muscle Tissue of Blue Swimming Crab Portunus pelagicus in Some Areas of the Southern Persian Gulf
}

\author{
${ }^{1}$ Department of Fisheries, University of Gonbad-e Kavous, Iran \\ ${ }^{2}$ Department of Fisheries, University of Gonbad-e Kavous, Iran \\ ${ }^{3}$ Department of Chemistry, University of Hormozgan, Iran \\ ${ }^{4}$ Department of Fisheries, University of Gonbad-e Qabus, Iran \\ ${ }^{5}$ Department of Fisheries, University of Gonbad-e Kavous, Iran
}

Naser Koosej ${ }^{1 *}$, Hojatollah Jafariyan², Abdolvahed Rahmani ${ }^{3}$, Abdolrahman Patimar ${ }^{4}$ and Hosna Gholipoor ${ }^{5}$

Submission: April 21, 2017; Published: June 01, 2017

"Corresponding author: Naser Koosej, Department of Fisheries, University of Gonbad-e Kavous, Iran, Email: naserkooseg@yahoo.com

\begin{abstract}
Heavy metals from industrial development and release it at a cost, which is resistant against degradation and the amount of fish as a human food chain accumulate. The objective of this study was to evaluate and compare the concentration of heavy metals, lead, nickel, iron, zinc and copper in muscle tissue of blue swimming crab Portunus plagicus in three regions (Qeshm, Khamir port left port) was conducted in the Hormozgan Province. Sampling was conducted in summer and winter 1394. After the captured biometric sample 180, was isolated muscle tissue. The preparation and analysis of samples was performed according to standard methods MOOPAM. Data analysis was performed using (SPSS) software, version 19 to compare of heavy metals ANOVA and Tukey tests were used in the study. The results show that the studied concentration in muscle tissue of blue swimming crab (Portunus pelagicus) at sample locations statistically significant difference shows. Also studied in terms of concentration in the muscle tissue of blue swimming crab in the study area between summer and winter statistically significant difference was observed $(\mathrm{p}<0 / 05)$. As both in summer and winter concentrations of lead, nickel, iron and copper in muscle tissue of blue swimming crab in Qeshm is greater than the other two regions. Meanwhile, the results of the study compared concentration in muscle tissue showed blue swimming crab with international standards. The studied concentration in muscle tissue of blue swimming crab in Qeshm, Khamir port and Laft port international standards is less than the limit. Which indicates that the health of aquatic ecosystems contamination is not a problem?
\end{abstract}

Keywords: Blue swimming crab; Portunus pelagicus; Heavy metals; Food chain; Persian gulf; Hormozgan of province

\section{Introduction}

Persian Gulf as a semi-closed marine environment in addition to the usual pollution in other rivers, due to extensive exploitation of huge oil reserves on the continental shelf and transfers it has caused a lot of oil and oil tankers, to the load imposed on each square kilometer of surface waters is greater than the global average. So enjoyed about half of the crude oil and oil products exported by ships from the Gulf passes and the pollution from the transportation of oil in the Persian Gulf about $86 \%$ of oil pollution in the Gulf is estimated. As compared to about 2 times that of pollution of marine transportation worldwide Abbaspoor [1]. Among the pollutants, non-degradable pollutants (persistent pollutants) such as heavy metals in sediments and mud and sludge concentrated as potential marine pollution and at the same time accumulate in aquatic and body tissue and concentrated And fish consumption may be toxic to humans and severe adverse effects such as disorders of the nervous system, renal, genetic mutations, and so on to be created, It is of utmost importance. Among the heavy metals $\mathrm{Pb}, \mathrm{Ni}, \mathrm{Fe}, \mathrm{Zn}$ and $\mathrm{Cu}$ indices, oil pollution and pollution from industrial activities in the marine ecosystem, the capacity of ecosystems to accept the changes in the environment and although, by its nature has the ability to cope with change But today it is clear that destruction has been the speed of natural regeneration. And the process for irreversible environmental degradation is growing, so measures to protect the environment should ponder Ganjavi et al. [2]. In addition, today one of the major concerns in the discharge of heavy metals into the marine environment is all over the world. And is well established that heavy metals cause toxicity and accumulation of 
ecological significance are many, these elements have devastating effects on the marine ecosystem and species diversity Agah et al. [3]. Lead one of four metals that have the most damaging effects on human health. Bio-synthesis of hemoglobin disorders and anemia, high blood pressure, kidney damage, miscarriage and preterm birth, nervous system disorders, brain damage, infertility in men, decreased learning ability and behavioral disorders and hyperactivity in children from the negative effects of increasing the concentration of lead in body EPA [4]. Nickel toxicity varies widely and is affected by salinity and the presence of other ions is placed. Industrial and commercial use of nickelcontaining stainless steel, plating, painting and ceramics are. Nickel also from anthropogenic sources enters the water system. Small amounts of nickel in people who are allergic to this heavy metal can cause severe inflammation of the skin EPA [4]. Zinc is one of the natural elements in building the body's cells and many enzymes and hormones involved. The metal body with many vital macromolecules are irreversibly linked and threatened to disrupt the biological activity of cells. Zinc also causes gastrointestinal disturbances such as nausea, vomiting, dry mouth, fever, headache and neurological disorders and respiratory diseases are also on the human body in high concentrations in the prostate, bone, muscle and liver accumulates Merian [5]. Copper natural entrance to the marine environment caused by the erosion of the cliffs is mine, is estimated at around 325000 tonnes per year. High levels of sewage into the sea. Copper dissolved in seawater, mainly in the form of water with low salinity $\mathrm{CaCo}_{3}$ and is also seen as $\mathrm{CuOH}^{+}$. In addition, the complex organic molecules are formed. Copper metal originating from various industries and by phytoplankton enters the food chain Babai \& Kermanshahi [6]. Iron is an important component of hemoglobin and transfer of blood and oxygen in the human body. If you do not hit the iron with body tissues or stay in them, causing conjunctivitis, inflammation problems in the choroid and retina. Normally, the body needs iron to 4 to 5 grams distributed in various tissues. The body's ability to excrete iron is not greater than $2 \mathrm{mg}$ per day and hence excessive intake of iron accumulation in the target organ and primarily eat more than 30 milligrams per kilogram of iron can lead to toxicity and more than 250 to $300 \mathrm{mg}$ kg leads to death Babai \& Kermanshahi [6]. Today, aquaculture as one of the most useful animal protein has been proposed for providing food needs and protects the human health around the world. Because of the harmful effects of heavy metals that are toxic in small amounts in water resources management with continuous measurement will be necessary Agbozu et al. [7]. Crabs are omnivorous crustaceans, especially from algae and other foods, including molluscs, worms, other crustaceans, fungi, bacteria in foods and feeds that are available to them. For many crabs a diet containing plant material and animal growth is faster and more survive them Kumar \& Hillegersberg [8]. The most important control methods, choice of different fish species widely to the physiological effects of heavy metals can be used Obasohan [9]. Thus, the concentration of heavy metals in the tissues of aquatic can be a prelude to detect the level of aquatic pollution Dugo et al. [10]. Such as indicator species to measure the amount of pollution can be traced to the blue swimming crab Portunus plagicus.

\section{Material and Methods}

Heavy metals are hazardous pollutants that waste and sewage into the sea. Aquaculture can act as a measure of pollution in aquatic ecosystems. Therefore, measurement and evaluation of a number of toxic elements and heavy metals (lead, nickel, iron, zinc and copper) in the muscle tissue of blue swimming crab Portunus pelagicus stations (Qeshm, Khamir port and Laft port) in the Persian Gulf was the basis for this study. After determining the three stations, in every season of every station, 30 type of blue swimming crabs were sampled, so that were collected randomly in every season of collect 90 type and total two season 180 sample. After the biometrics, autopsy was performed and was isolated muscle tissue. So that for dry crap muscle tissues put in the freeze dryer (VaCo5 model) at 40 $-{ }^{\circ} \mathrm{C}$ for 8 to 10 hours. So after running out the time and ensure complete dry of muscle tissue, the samples are removed balloons and in the petri dishes were placed numbered Moopam [11]. In order to digest the samples were ground with a porcelain mortar laboratory. the First, was measured (0.5gr) amount of dried samples tissue by" Sartorius scales"-made in Germany- with accuracy equivalent 0.001 grams. The sample is poured shed into a microwave vial (ETHOS1, model) and after the addition of $7 \mathrm{ml}$ of concentrated nitric acid 65\% (after the using porcelain mortar any time, washed with nitric acid $5 \%$ and was completely rinse with distilled water) so $1 \mathrm{ml}$ hydrogen peroxide (30\%), closed the door's vials and those are placed in a special chamber, next transferred to the microwave Moopam [11] and according to the order digest the sample. After digestion and cooling time, the samples were removed from the device and were pure through Whitman filter paper number 42 . The content of the filter was washed with distilled water. So samples liquid ready discharged into the beakers and were dried in the laboratory's temperature. After dried, samples mixed through distilled water and samples deliver to the volume 50 with pure distilled water. So sample kept in polyethylene containers and stored at $4^{\circ} \mathrm{C}$ (to avoid any reduction in the volume). Obviously storage time should not be long and after digestion of the samples, they injected the atomic absorption and their actual chemical concentrations were calculated. The chemical digestion is based on accepted MOOPAM Moopam [11]. Data analysis was performed using SPSS 19 software and analysis of means to help T- test were compared with the presence or absence of a significant difference at 95\% (P $<0.05$ ) was determined. As well as charts and tables Excel2007 software was used.

\section{Results and Discussion}

Analysis of variance showed that the concentrations of lead, nickel, iron, zinc and copper in muscle tissue of blue swimming crab Portunus pelagicus between island regions, Bndrkhmyr and Bndrlaft in winter there is a significant difference $(\mathrm{P}<0.05)$. As 
the studied concentration in the muscle of blue swimming crab in winter Qeshm higher rates than areas (Khamir port and Laft port) and the difference was statistically significant $(\mathrm{P}<0.05)$. (Table 1, Figure $1 \& 2$ ).

Table 1: compares the results of the average of the elements nickel, lead, iron, zinc and copper in muscle tissue of blue swimming crab in winter in Qeshm, Khamir port and Laft port (mean $\pm S D),(n=30)$.

\begin{tabular}{|c|c|c|c|}
\hline Laft Port & Khamir Port & Qeshm & Index Area \\
\hline $0 / 04 \pm 0 / 37$ & $0 / 02 \pm 0 / 64$ & $0 / 05 \pm 0 / 84$ & $\begin{array}{c}\text { Nickel (micrograms } \\
\text { per gram) }\end{array}$ \\
\hline $0 / 002 \pm 0 / 014$ & $0 / 003 \pm 0 / 018$ & $0 / 006 \pm 0 / 031$ & $\begin{array}{c}\text { Lead (micrograms } \\
\text { per gram) }\end{array}$ \\
\hline $1 / 20 \pm 55 / 60$ & $1 / 11 \pm 77 / 2$ & $1 / 90 \pm 88 / 3$ & $\begin{array}{c}\text { Zink (micrograms } \\
\text { per gram) }\end{array}$ \\
\hline $0 / 65 \pm 13 / 75$ & $0 / 48 \pm 17 / 22$ & $0 / 16 \pm 19 / 33$ & $\begin{array}{c}\text { Iron (micrograms } \\
\text { per gram) }\end{array}$ \\
\hline $0 / 014 \pm 0 / 621$ & $0 / 031 \pm 0 / 718$ & $0 / 025 \pm 0 / 801$ & $\begin{array}{c}\text { Cu (micrograms per } \\
\text { gram) }\end{array}$ \\
\hline
\end{tabular}

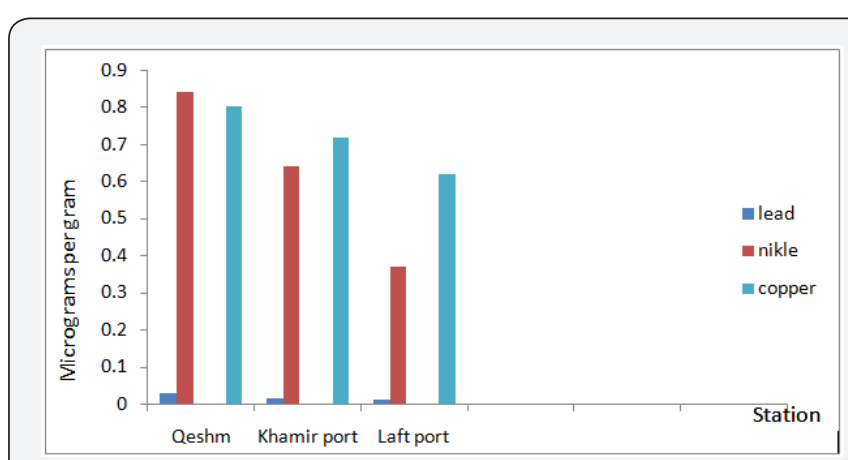

Figure 1: Comparison of nickel, lead and copper in blue swimmer crab muscle in Qeshm, Khamir port and Laft port in winter.

The results of ANOVA showed that the concentrations of lead, nickel, iron, zinc and copper in muscle tissue of blue swimming crab Portunus pelagicus between regions (Qeshm, Khamir port and Laft port) there was no statistically significant difference in summer $(\mathrm{P}<0.05)$. So in terms of concentration in the muscle tissue of blue swimming crab in the summer Qeshm higher rates than areas (Bndrkhmyr and Bndrlaft), and the difference was statistically significant $(\mathrm{P}<0.05)$. (Table 2 , Figure $2 \& 3$ ).
Table 2: compares the results of the average of the elements nickel, lead, iron, zinc and copper in muscle tissue of blue swimming crab in the summer in Qeshm, Khamir port and Laft port (mean \pm SD), $(n=$ $30)$.

\begin{tabular}{|c|c|c|c|}
\hline Laft Port & Khamir Port & Qeshm & Index Area \\
\hline $0 / 03 \pm 0 / 58$ & $0 / 02 \pm 0 / 75$ & $0 / 05 \pm 0 / 97$ & $\begin{array}{c}\text { Nickel (micrograms } \\
\text { per gram) }\end{array}$ \\
\hline $0 / 002 \pm 0 / 021$ & $0 / 003 \pm 0 / 026$ & $0 / 005 \pm 0 / 038$ & $\begin{array}{c}\text { Lead (micrograms } \\
\text { per gram) }\end{array}$ \\
\hline $1 / 74 \pm 64 / 70$ & $1 / 32 \pm 81 / 02$ & $1 / 74 \pm 109 / 4$ & $\begin{array}{c}\text { Zink (micrograms } \\
\text { per gram) }\end{array}$ \\
\hline $0 / 42 \pm 16 / 05$ & $0 / 19 \pm 19 / 93$ & $0 / 22 \pm 25 / 59$ & $\begin{array}{c}\text { Iron (micrograms } \\
\text { per gram) }\end{array}$ \\
\hline $0 / 035 \pm 0 / 733$ & $0 / 015 \pm 0 / 791$ & $0 / 018 \pm 0 / 897$ & $\begin{array}{c}\text { Cu (micrograms } \\
\text { per gram) }\end{array}$ \\
\hline
\end{tabular}

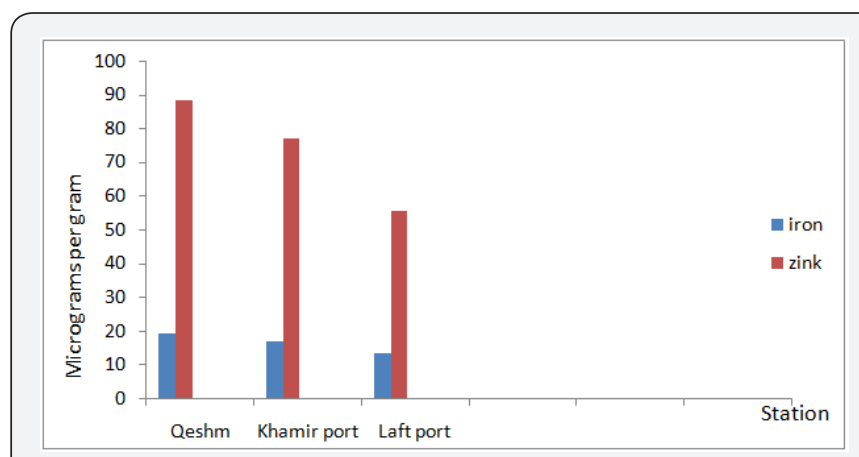

Figure 2: Comparison of Iron and zinc in blue swimming crab muscle in Qeshm, Khamir port and Laft port in winter.

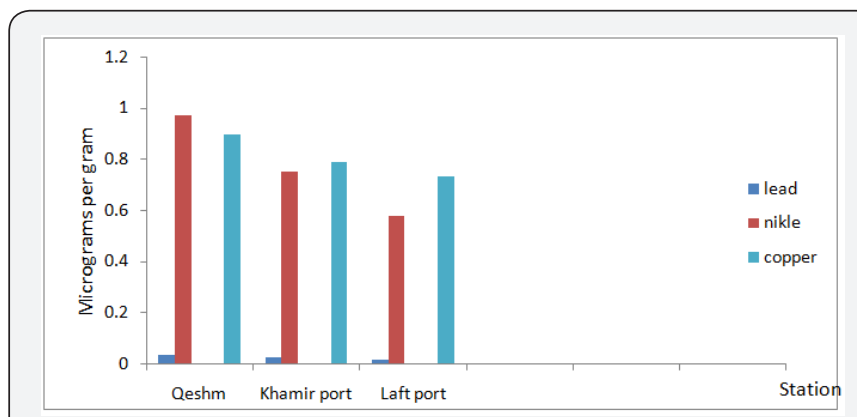

Figure 3: Comparison of nickel, lead and copper in blue swimmer crab muscle in Qeshm, Khamir port and Laft port in summer.

The results indicate that in all regions of concentration of heavy metals (lead, nickel, iron, zinc and copper) in summer than in winter (Table 3).

Table 3: results of the comparison of the average values of nickel, lead, iron, zinc and copper in blue swimmer crab muscle in Qeshm, Khamir port and Laft port in summer and winter (mean $\pm S D)),(n=30)$.

\begin{tabular}{|c|c|c|c|c|c|c|}
\hline \multirow{2}{*}{ Variable } & \multicolumn{2}{|c|}{ Qeshm } & \multicolumn{2}{c|}{ Khamir port } & \multicolumn{2}{c|}{ Laft port } \\
\hline & Winter & Summer & Winter & Summer & Winter & Summer \\
\hline $\mathrm{Ni}$ & $0 / 05 \pm 0 / 84$ & $0 / 05 \pm 0 / 97$ & $0 / 02 \pm 0 / 64$ & $0 / 02 \pm 0 / 75$ & $0 / 04 \pm 0 / 37$ & $0 / 03 \pm 0 / 58$ \\
\hline $\mathrm{Pb}$ & $0 / 006 \pm 0 / 031$ & $0 / 005 \pm 0 / 038$ & $0 / 003 \pm 0 / 018$ & $0 / 003 \pm 0 / 026$ & $0 / 002 \pm 0 / 014$ & $0 / 002 \pm 0 / 021$ \\
\hline $\mathrm{Zn}$ & $1 / 90 \pm 88 / 3$ & $1 / 74 \pm 109 / 4$ & $1 / 11 \pm 77 / 2$ & $1 / 32 \pm 81 / 02$ & $1 / 20 \pm 55 / 60$ & $1 / 74 \pm 64 / 70$ \\
\hline $\mathrm{Fe}$ & $0 / 16 \pm 19 / 33$ & $0 / 22 \pm 25 / 59$ & $0 / 48 \pm 17 / 22$ & $0 / 19 \pm 19 / 93$ & $0 / 65 \pm 13 / 75$ & $0 / 42 \pm 16 / 05$ \\
\hline $\mathrm{Cu}$ & $0 / 025 \pm 0 / 801$ & $0 / 018 \pm 0 / 897$ & $0 / 031 \pm 0 / 718$ & $0 / 015 \pm 0 / 791$ & $0 / 014 \pm 0 / 621$ & $0 / 035 \pm 0 / 733$ \\
\hline
\end{tabular}


Exploration, extraction and transportation of oil in the Persian Gulf, in addition to direct contamination, due to large amounts of heavy metals, chemical pollution of the Gulf marine and aquatic life is AL -Saleh \& Shinwari [12]. Fabris \& colleagues [13] showed that the concentration of heavy metals such as arsenic, cadmium, iron, zinc and mercury in fish and lobster J. Edwardsis P. bassen is ground now and abalone H. rubra to the location where the fish live in it. Depends on the concentration of the species in different parts of the coastal waters of Victoria in Australia there is a significant difference, but a pattern and there was no consistent trend across regions at a concentration of heavy metals. There are significant differences between the concentrations of heavy metals in different areas can be discussed and not because of different management application, environmental conditions, evacuation of wastewater, the presence of industrial plants and aquaculture activities in the areas. Chen [14], showed significant differences in the concentrations of lead, cadmium, mercury, silver, copper and iron Chi-Ku Lagoon was found in samples from different regions. He also said that in areas where the origin of pollutants from sewage or fresh water input. Cadmium, mercury and copper were present in the environment, while the entrance to the remote areas of the mouth and go wetland reduced concentrations of these elements. Dural \& colleagues [15], with several experiments showed that the concentration of heavy metals in aquatic organisms in different regions (the Persian Gulf, Gulf Egypt, the Gulf Askndryvn, in the South Atlantic salt marshes and wetlands Spain California) due to different environmental conditions such as : temperature, salinity, $\mathrm{pH}$ and light industrial activities.... and there is a significant difference. Turkmen \& colleagues [16] reported that concentrations of heavy metals in fish muscle, according to the area where the fish is caught. And according to the species of fish can be very diverse and vary, also showed. Although not different between the concentrations of heavy metals in different parts of sampling fish there are significant differences. Meador et al. [17], the concentration of three cadmium, mercury and lead in sediments and fish in several areas in Alaska and California have measured the results showed concentrations of lead and cadmium in sediments rural areas of California due to human activity is the because gasoline is increasing. A significant impact on aquatic habitats so that the concentration of heavy metals, heavy metals in organisms that live in the Gulf are less than the amount of heavy metals in the body of organisms in coastal waters and estuaries, bays and inlets are present Al- Yousef et al. [18]. Unfortunately, in the discharge of sewage and solid waste and industrial development and dredging operations off the coast and ports, unloading of agricultural pesticides and fertilizers, as well as Persian Gulf oil extraction operations are heavily polluted with heavy metals and hydrocarbons is Ashraf $\mathrm{V}$ [19]. More pollutants into aquatic systems are eventually are deposited in the sediment. Sediments, aquatic environments are a critical component for performance and nutrition provide habitat for many organisms and in many cases the accumulation of metals in sediments than in the water Unlu et al. [20]. And semi-benthic benthic species vulnerable to contaminants in sediments and contaminants are water-soluble, This species also play a constructive role in this environment and therefore their demographic shifts affect all societies and threatens the balance of ecosystems Cogun et al. [21]. Generally, the most important reasons for the high concentration of lead, nickel, zinc, copper and iron in muscle tissue in the blue swimming crab in Qeshm island compared to Khamir port and Laft port in various industries along the coast, discharge of industrial effluents and urban coastal waters is that their wastewater in a variety of heavy metals, and this increases the concentration of these metals. On the other hand there dhow building yards along the waterfront of the island and the use of color and anti-corrosion material (which contains zinc chromate and lead oxides area and finally moved to the coastal waters and adjacent areas and water pollution in this area are), too Boat traffic (tourism and fishing activities) and the presence of lead and nickel in gasoline and publish it in the air, then lead and nickel from combustion and quickly deposited on the soil, The nickel-containing sediments by rivers to the Persian Gulf could also be other reasons for this increase. Fifteen mine soils are red, white, chalk, yellow sulfur, iron, stones and within $11 \mathrm{~km}$ of the island. The most active are red mineral containing abundant iron as well as a micronized powder production plant of red soil cited Island. On the other hand pollution caused by vessels traffic, repairs them (given that most people trade jobs and trade, fishing, boat-building and agriculture) should also be considered. The results of this study showed that the concentrations of the studied regions (Qeshm, Khamir port and Laft port) in summer than in winter blue crab floats statistically significant difference.

The concentration of heavy metals in the summer of aquatic organisms in the body often in locations in areas with industrial activities are free of contaminants and more Mendil et al. [22]. Wong et al. [23], with the amount of lead, cadmium, copper and zinc on the species Perna viridis in Hong Kong showed that the concentration of cadmium and copper all areas other than the significant difference in summer and winter there is significant. Dural \& colleagues [15], experimenting with a variety of fish Sparus aurata showed that the concentration of cadmium, lead, zinc and arsenic in different seasons and also heavy metals in different organs is different. Haji Hussain \& Ghasemi [24] examined the emissions of nickel, chromium, cadmium, lead, copper and iron is paid crap. The results of data analysis showed a significant difference in the amount of heavy metals in between there, the average concentration of all parameters in the months of February, March, April and May, and in other months less than the standard limit is exceeded. Another important factor of increasing concentrations of heavy metals, salinity, which is more subject to climate change sea water in winter as in summer minimum and maximum amount of salt in sea water. There is a direct relationship between temperature and salinity suggests that with increasing temperature, salinity rises. Given that the air temperature in the hottest days of summer in August to 45 degrees Celsius, thereby also increasing the amount of 
evaporation and salinity. Because in some seasons, especially summer Persian Gulf under the influence of Oman Sea and other waters that are input to the conclusion of some metals due to variations in salinity and quicker to settle. The heavy metals are directly related to the amount of water salinity, possibly Another factor is the increasing amount of these metals in the summer Kafilzadeh et al. [25]. They crabs are omnivorous, especially from algae and other foods, including molluscs, worms, other crustaceans, fungi, bacteria in foods and feeds that are available to them For many crabs a diet containing plant material and animal growth is faster and more survive them Kumar \& Hillegersberg [8]. Fish and other cold-blooded creatures like crabs Portunus plagicus Shnagra by are a function of ambient temperature. And because of the drop in temperature in winter, these creatures are also experiencing lethargy and less to feed out of their nests and would rather have more time to stay in their nests Caran [26]. Wassenberg \& Hill [27] reported that a large amount of fish that can be eaten by crabs are dead fish carcasses as waste by local fishermen catch shrimp fishing season to catch the throw. And also because shrimp fishing in late summer and early autumn. This also corresponded with our observations in our study because the heavy metal lead, nickel, zinc, copper and iron in the summer than in winter. In general, this study showed that the area of study in terms of the amount of lead, nickel, copper, zinc and iron in muscle blue swimming crab are infected but lower than global standards [28-30].

\section{References}

1. Abbaspoor M (1377) Engineering the environment first volume. Azad University, India, p. 258.

2. Ganjavi M, Panah EH, Givianrad MH, Shams A (2010) Effect of conned tuna fish processing steps on lead and cadmium contents of Iranian tuna fish. Food Chemisty 118(3): 525-528.

3. Agah H, Makers LM, Elskens MS (2008) Accumulation of trace metals in the muscle and liver tissues of five speciies from the Persian Gulf. Environ Monit Assess 157: 499-514.

4. EPA (1997) Drinking water standards Environment of Criteria and Assess.

5. Merian E (1992) Metals \& their compounds in environment. Journal of Environmental Healt Criteria 4: 63-53.

6. Gol BS, Kermanshah E (1380) contamination of heavy metals in river water West of Gilan (Shafaroud, Korgon River, Havigh). Project reports Guilan Fisheries Research Center, p. 54.

7. Agbozu IE, Ekweozor IK, Opuene EK (2007) Survey of heavy metals in the catfish (Synodontis claris). Environmental science Technology 4: 93-97.

8. Kumar K, Hillegersberg JV (2000) ERP Experiences and Evolution Communications of the ACM 43(4): 23-26.

9. Obasohan EE (2007) Heavy metals concentration in the offal, gill, muscle and liver of a freshwater mudfish (parachanna obscura) from Ogba River, Benin City, Nigeria. African Journal of Biotechnology 6: 2620- 2624.

10. Lapera DG, Bruzzes LA, Pellicano T, Lotorco MV (2006) Concentration of $\mathrm{Cd}, \mathrm{Cu}, \mathrm{Pb}$, Se and $\mathrm{Zn}$ in cultured sea bass (Dicentrarchus labrax) tissue from Tyrrhenian sea and Silcilian sea by derivative stripping potentiometer. Food Control 17: 146- 152.
11. Moopam (1999) Manual of oceanographic observations and pollutant analysis methods. ( $3^{\text {rd }}$ edn), Kuwait, p. 321.

12. AL-Saleh I, Shinwari N (2002) Preliminary report on the levels of elements in four fish species from the Persian Gulf of Saudi Arabia. Chemo Sphere 48: 749-755.

13. Fabris G, Turoczy N, Sment J, Stagnitti F (2006) Tract metals concentration in edible tissue of snapper, flathead and ablone from coastal waters of Victoria. Australia Ecotoxicology and Environmental Safety 63: 286-292.

14. Chen MH (2002) Baseline metal concentration in sediments and fish and determination of bioindicators in the subtropical. Baseline Marine Pollution Bulletin 44: 703-714.

15. Dural M, Goksu MZL, Ozak A (2007) Investigation of heavy metal levels in economically important fish species from the Tuzla lagoon. Food Chemistry 102(1): 415- 421.

16. Turkmen A, Tqe TM, Y Akyu I (2005) Heavy Metals in Three Commercially valuable fish species from Iskenderun Bay, North East Mediterranean Sea. Turkey Food Chemistry 91: 167-172.

17. Meador J, Erest D, kagley A (2005) A comparison of the non- essential elements cadmium , mercury and lead foud in fish and sediment from alska and California. Science of the Total Enviroment 339(1-3): 189205.

18. Al- Yousef M, EI- shahawi MS, Al-Ghais SM (2000) Trace metals in liver, skin and muscle of Lethrinus lentjan fish species in relation to body length and sex. Science Total Environment 256(2-3): 87-94.

19. Ashraf V (2005) Accumulation of heavy metals in kidney and heart tissues of Epinephelus microdon fish from the Persian Gulf. Journal of Environmental Monitoring and Assessment 101: 311-316.

20. Unlu S, Topcuoglu S, Alpar B, Kirbasoglu C and Yilmaz Y Z (2008) Heavy metal pollution in surface sedimentns and mussel samples in the Gulf of Gemlik. Journal of Environmental Monitoring and Assessment 144: 169-178.

21. Cogun HY, Yuzereroglu TA, Firat O, Gok G, Kargin F (2006) Metal concentrations in fish species from the Northeast Mediterranean Sea. Journal of Environmental Monitoring and Assessment 121(1): 431438.

22. Mendil D, Unal OF, Tuzen M, Soylak M (2010) Determination of trace metals in different fish species and sediments from the river Yesilirmak in Tokat, Turkey. Food and Chemical Toxicology 48(5): 1383-1392.

23. Wong CKC, Cheung RYH, Wong MH (2000) Heavy metals concentration in green- liped mussels collected from Tolo harbor and markets in Hong Kong and Shenzhen. Environmental pollution 109(1): 165-171.

24. Hussain H, Nouhi SA, Ghasemi M (1980) Determine the amount of inorganic contaminants in Shehrchay, Livestock and Natural Resources Research Center of East Azarbayjan Province, the first national conference on Iran and environmental crises improve their work.

25. Kafilzadeh F, Esmaeili Sari AS, Fatemi SAD, GH Vosoughi N (1382) Investigate the relationship between oil pollution incidents density construction in the Persian Gulf pearl. Journal of Fisheries 4: 127-141.

26. Caran J (1943) Crabs from the genus Uca from the west coast of central America. Zoological 26: 145-208.

27. Karbasi AS (1379) Standard concentration and origin of Ni- Zn- Cu- Co$\mathrm{Cd}-\mathrm{V}$ - Fe- Mn- Pb in surface sediments of the Persian Gulf. The journal Environmental Science and Technology 5(6): 65-53.

28. Wassenberg TJ, Hill BJ (1987) Natural diet of the tiger prawns Penaeus esculentus and P semisulcatus. Aust J mar Freshwat Res 38: 169-18.

29. Khansari EF, Ghazi-Khansari M, Abdollahi M (2004) Heavy metals content of canned tuna fish. F Chem 93(2): 293-296. 
30. Ruangsomboom S, Wongrat L (2006) Bioaccumulation of cadmium in an experimental aquatic food chain involving phytoplankton (Chlorella

This work is licensed under Creative

Commons Attribution 4.0 License

DOI: 10.19080/ARTOAJ.2017.07.555714 vulgaris), zooplankton (Moina macrocopa), and the predatory catfish Clarias macrocephalus and C. gariepinus. Aquatic Toxicol 78(1): 15-20.

Your next submission with Juniper Publishers
will reach you the below assets
- Quality Editorial service
- Swift Peer Review
- Reprints availability
- E-prints Service
- Manuscript Podcast for convenient understanding
- Global attainment for your research
- Manuscript accessibility in different formats
( Pdf, E-pub, Full Text, Audio)
- Unceasing customer service
Track the below URL for one-step submission
https://juniperpublishers.com/online-submission.php

